\title{
A Magyar Nemzeti Bank 1950 és 1990 között megjelenő, magyar nyelvü kiadványainak vizuális kommunikációs szempontú bemutatása*
}

\author{
Vajas Ákos
}

\section{Bevezetés}

A Magyar Nemzeti Bank nevének hallatán az emberek többsége akaratlanul is egyszerre a Szabadság tér mellett található főépületre gondolhat. Nem meglepő, hiszen olyan karakteres és jellegzetes épületről beszélünk, amelynek építészeti stílusa, a homlokzatát borító szobor-együttesek, valamint az épület belsejét díszítő üvegablakok is mind kiváló építészek, szobrászok és iparmúvészek kezének kimagasló alkotásai. A Bank az épületén keresztül, amely már hosszú-hosszú évtizedek óta szolgál székhelyéül szakmai tevékenységének - szimbólumszerepet tölt be a hazai, valamint nemzetközi pénzügy- és gazdaságpolitikában. Annak ellenére, hogy a Bank fóépületéről számos könyv, illetve bemutatás született már különböző szerzők alapos és részletes munkája révén, valahogy mégis kevés szót ejtünk a Bank múltbeli életében szerepet vállaló szakemberekről, azok közösségéről és szerepvállalásairól, valamint közvetlenül a Bank által kiadott kiadványokról, belső és külső terjesztésű egyszerü tájékoztatási- vagy komoly szakmai publikációs felületet jelentő folyóiratairól. A különböző kiadványok nemcsak vizuális megjelenésük miatt lehetnek érdekesek és értékesek számunkra, hanem tartalmuk tekintetében is igazi ritkaságnak számítanak. A külső mögött ugyanis olyan különleges betekintési lehetőséget kapunk, amelyen keresztül megismerhetővé, megérthetővé és kicsit átélhetővé teszi számunkra a Bank régmúltjának minden egyes mozzanatát (például: a II. világháború alatti és utáni személyes visszaemlékezések, az 1956-os forradalom és utózengései a Bankon belül stb.). Nemcsak a leírások, hanem az itt található illusztrációk, karikatúrák és grafikák is kimagasló színvonalúak, amelyek nem csak egy szervezet mindennapi eseményeinek, hanem a tudományterület (közgazdaságtan) egészének is görbe tükröt tartanak. Sőt olykor őszinte reflexióikat is viszontláthatjuk az 1945 és 1990 közötti kor társadalmi és politikai berendezkedésével, légkörével kapcsolatosan. E rövid, de közel sem teljes körű bemutatás azzal a céllal jött létre, hogy egyrészt felkeltse

* Jelen cikk a szerző nézeteit tartalmazza, és nem feltétlenül tükrözi a Magyar Nemzeti Bank hivatalos álláspontját.

Vajas Ákos a Magyar Nemzeti Bank projekt koordinátora. E-mail: vajasa@mnb.hu

A magyar nyelvű kézirat első változata 2017. szeptember 11-én érkezett szerkesztőségünkbe.

DOI: http://doi.org/10.25201/HSZ.16.4.201214 
az érdeklődést az olvasókban a vizuális kommunikáció iránt, amely kevéssé van fókuszban a közgazdaságtan területén, másrészt ily módon tisztelegjek és emlékezzek meg a Bankszemléről a 60 évvel ezelőtti elindulásának az évfordulója alkalmából.

\section{Bankszemle}

Az 1957 júniusában megjelenő Bankszemle (1. ábra) a Magyar Nemzeti Bank szakmai és tudományos folyóirata volt, amely kezdetben csak belső használatra és terjesztésre készült. A szakmai kiadvány kezdetben 350 példányban készült, fokozatosan 1 000-ig emelkedve. A tartalmát föleg a banki dolgozók írták és olvasták is zártkörü terjesztése miatt. Később, az arculati és tördelési újításokkal párhuzamosan - bővítették a folyóirat terjesztési körét - ezáltal elérhetővé vált számos más pénz-

1. ábra
A Bankszemle arculatváltásai
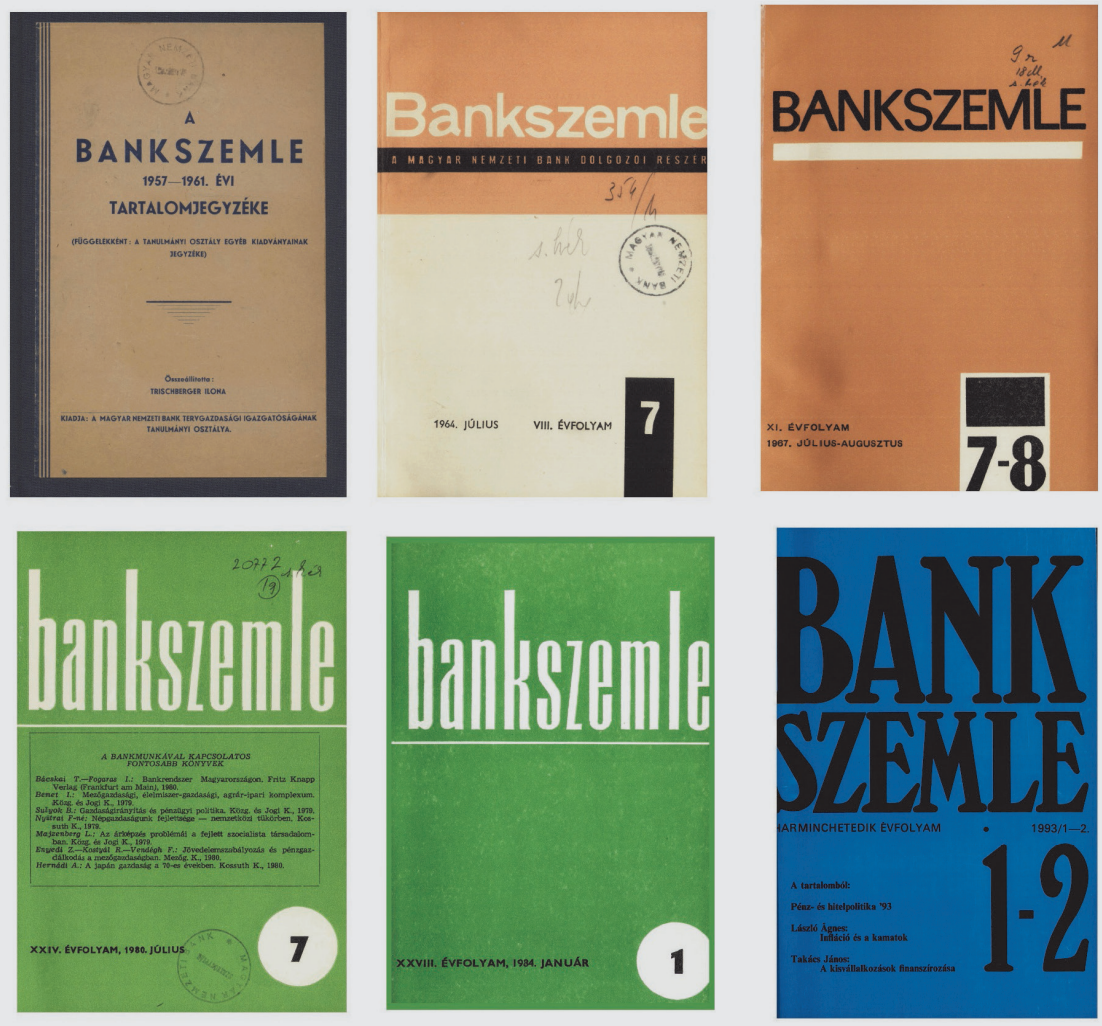

${ }^{1}$ A Bankszemle 2001-ig került kiadásra, ekkor helyét a Hitelintézeti Szemle vette át a közgazdasági és pénzügyi szakterület egyik meghatározó hazai tudományos szakfolyóirataként. 
ügyi intézet, szervezet és vállalat számára -, másrészt nyitottá tették a publikálás lehetőségét a bankon kívüli szakemberek számára is. Ennek eredményeképpen a folyóirat előfizetői létszáma az ezres nagyságrendről felugrott háromezer köré, amivel országosan is meghatározó szakmai folyóirattá vált. Jól látható, hogy az évtizedek során a kiadvány külsőleg némileg változott, de tematikailag annál kevesebbet. Az arculatváltás és föleg a kiadvány belső oldalainak (belívek) tördelésének a megújításával szerették volna támogatni a lapban megjelenő szakmai tartalmak megjelenésének színvonalát és presztízsét ${ }^{2}$. A sokáig 80 oldal terjedelemben megjelenő folyóirat 64 oldalra csökkentésével sikerült karcsúsítani a kiadvány megjelenését, viszont az új tördelési technikákkal képesek voltak növelni a tartalmak hosszúságát, illetve a szerkesztés módosításával (például kéthasábos elrendezés) megkönnyíteni a szakmai szövegek olvashatóságát.

\section{Forint magazin}

1950. augusztus 15-én jelent meg a Forint, a Magyar Nemzeti Bank dolgozóinak a folyóirata ${ }^{3}$, amelynek elődje a Bankújság nevet viselte ${ }^{4}$, testvérlapjai pedig a Fillér ${ }^{5}$ és a Bankó ${ }^{6}$ voltak (2-3. ábra). A Forint 1951 őszétől - papírhiány miatt - szünetelt, és csak 1957-ben vált újra elérhetővé7. A belső terjesztésű magazin a bank aktívés nyugdíjas dolgozóinak is az egyik legfőbb társadalmi és véleménynyilvánítási platformja volt. Az esetlegesen Üzemi Híradó, vagy legtöbbször Magyar Nemzeti Bank Dolgozóinak Lapja titulust viselő folyóirat minden szempontból talán az egyik legautentikusabb forrást kínálja ahhoz, hogy betekintést nyerjünk a Bank egykori mindennapjaiba.

\footnotetext{
${ }^{2}$ Az arculatváltások szükségességéről dr. Zádori János egykori főszerkesztő a Forint magazin 1986-os januári számában (11. oldal) a következő módon nyilatkozott: „A Bankszemle felett eljárt az idő, Magyarországon a mi lapunk volt az egyetlen kisméretü folyóirat. Olyan jellegtelen külsejü, tipográfiailag igénytelen lapban a színvonalas írások sem érvényesülhettek."

${ }^{3} \mathrm{~A}$ folyóirat az aranykorában - 1975 környékén - közel 3600 példányban jelent meg, ami később lassú ütemben, de fokozatosan csökkenni kezdett. Továbbá ebből fakadóan is a kezdeti előfizetéses alapon múködő terjesztési rendszert később - az 1990-es évek fordulóján - felváltotta az ingyenes elérhetőség, aminek célja az volt, hogy megakadályozza a folyóirat példányszámesését.

${ }^{4}$ Az újság 1949. december 21-től 1950. július végéig létezett (Botos - Botos, 2004)

${ }^{5}$ A Magyar Kommunista Ifjúsági Szövetség (KISZ) kiadványa volt, amelynek tartalma és színvonala meg sem közelítette a Forintét.

${ }^{6}$ A Pénzjegynyomda hivatalos kiadványa volt, amely 1958 áprilisában jelent meg első alkalommal.

71953 júniusa után a Forint társadalmi tájékoztatási funkcióját a stencilezett formában közreadott Híradó töltötte be.
} 


\section{2. ábra}

A Bankújság 1949-1950 közötti, majd Forint 1950 és 1989 között kiadott borítóinak az átalakulása

(1. rész)
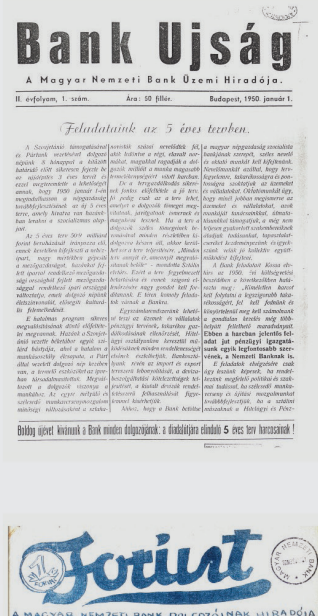

A DICSÖSÉCES MACYARTANACS KÖTA'RSASA'C KIKIALLTA'SA'NAK

dén évfordulója
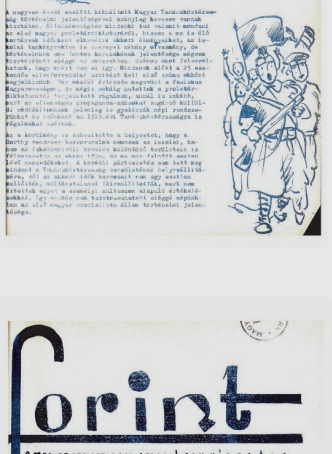

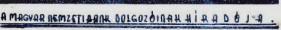

moro elsgie

${ }^{2950}$

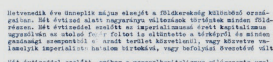

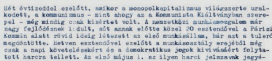

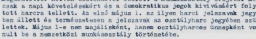

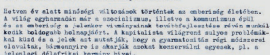
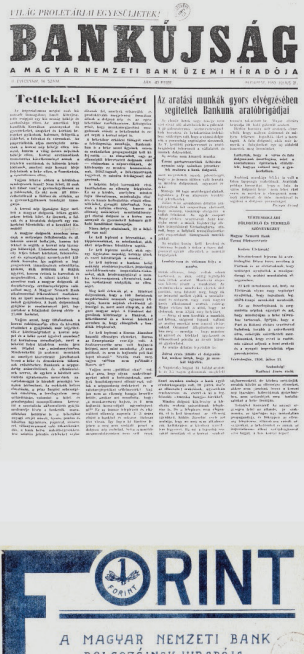

MAGपAR MEMZETI BA
DOLGOZÓINAK HIRADÓJA

A POLCA'RI TORVENYKONYY

JELENT ÖSËCE A BANK MUNKATERÜLETEN

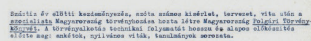

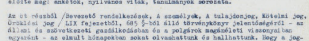

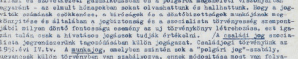



sins

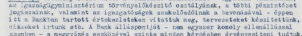

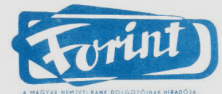

BANKUNK AZ UJ MECHANIZMUSBAN

$5=-3-5=5=$

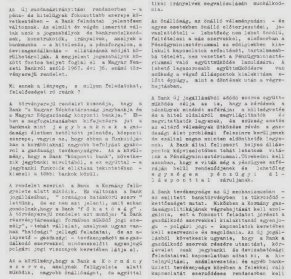

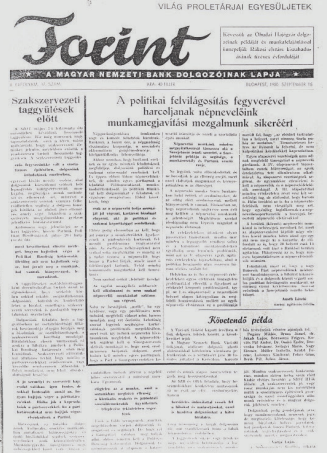

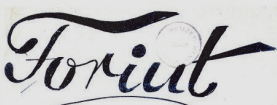

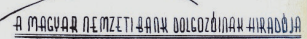

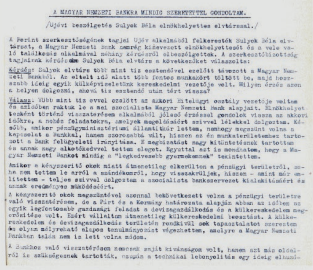

FORINT
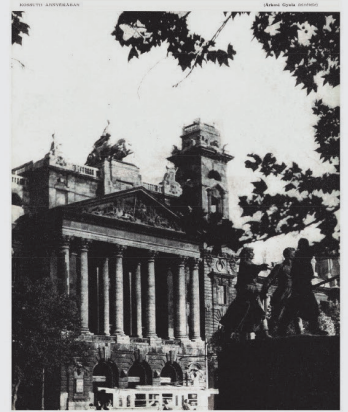


\section{3. ábra}

A Forint 1950 és 1989 között kiadott borítóinak az átalakulása

(2. rész)
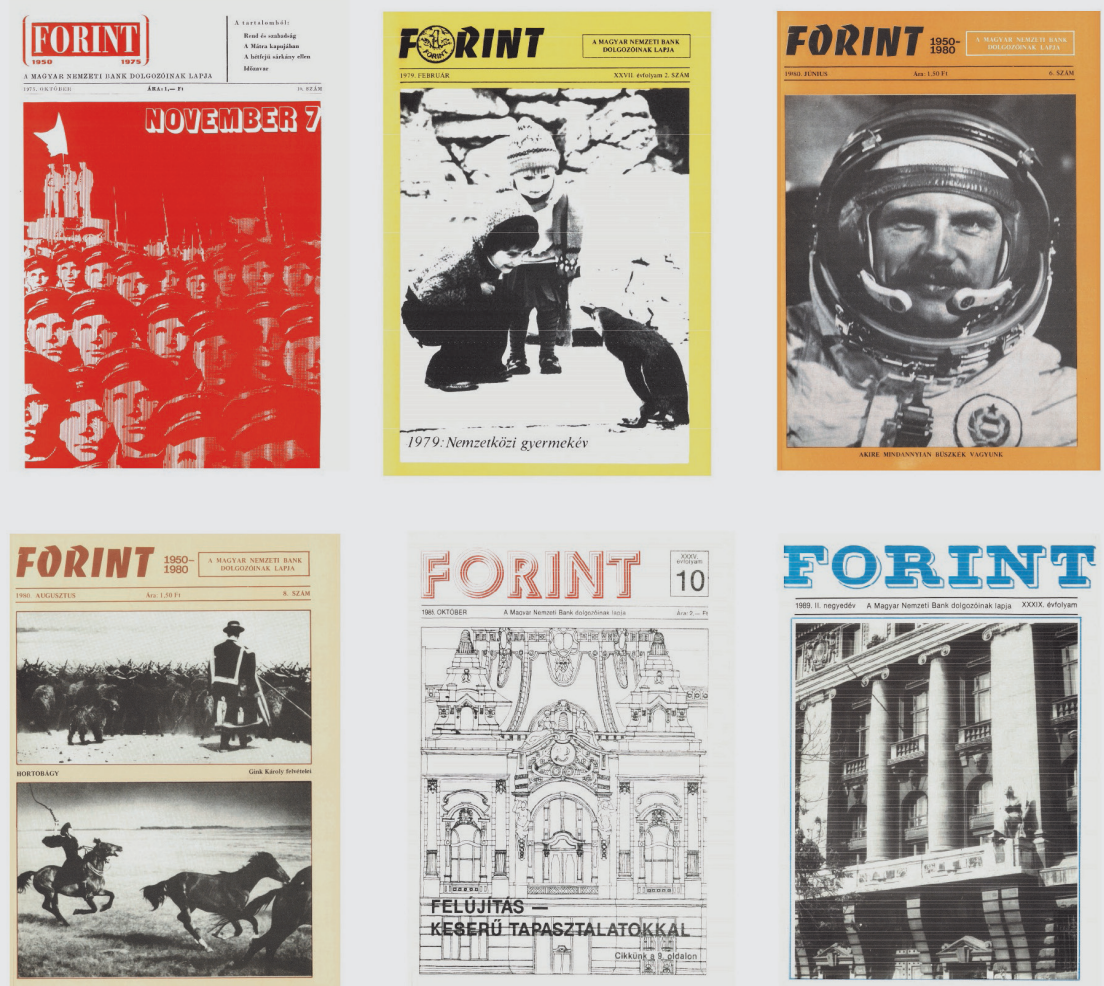

A folyóiratot 1969-től egy külső nyomda (Kossuth nyomda) állította elő, amit 1979től felváltott a Magyar Nemzeti Bankon belüli belső sokszorosítás. Ez az áttérés lerövidítette a nyomdai átfutási időt és technikai újításokat is hozott magával az előállítás kapcsán. Olyan újszerű laptördelési lehetőségekre nyílt mód, ami egyrészt lehetővé tette a folyóirat tartalmi bővítését és megújítását, másrészt elősegítette és javította a tartalmak olvashatóságát, strukturáltságát. Ezek az újító lépések azonban nemcsak a szöveges, hanem a vizuális tartalom elhelyezésére is pozitív hatást gyakoroltak. Ennek egyik legszembetűnőbb eleme az újság borítójának és fejlécének tartalmi és képi átalakulása, ami időről-időre fokozatosan finomodott és egyre változatosabbá, izgalmasabbá vált. A szövegközpontú és egyszínű borítókat felváltották a színes háttérrel rendelkező, kezdetben rajzokkal, vagy fekete-fehér, majd az 1990-es évek után színes fényképekkel illusztrált fedőlapok. A tördeléstechnika révén kiegyensúlyozottá vált a folyóirat szöveg-kép közötti aránya, ugyanis fokozatosan előtérbe kerültek 
a szövegközi illusztrációk, erősítve és kiegészítve az írott tartalmak mondanivalóját, továbbá megjelentek a véleményformálást támogató karikatúrák is, mint önálló és egyedi vizuális kommunikációs eszközök.

Ezek középpontjában egyrészt a közgazdaságtan és általánosságban véve a gazdasághoz és a pénzügyekhez kötődő témakörök (például Közgazdasági kislexikon vagy az Értelmező bankszótár sorozat), másrészt a Bank mindennapi életéhez kapcsolódó különböző problémák és élethelyzetek ábrázolásai foglaltak helyet (például bankon belüli helyhiány és a szobák zsúfoltsága, az állandóan elromló lift stb.). Ezektől teljesen függetlenül természetesen találkozhattunk általános társadalmi témákat felölelő rajzokkal is (például a Fintor sorozat kapcsán). A lap egyik különlegességét adták a nem is olyan ritkán megjelenő fél- vagy egész oldalas illusztrációk, amelyek a mostanában is nagyon népszerű történetmesélős (storytelling) hangulattal rendelkező ábrázolásokat juttathatják az eszünkbe.

A Forint tartalmi felépítését áttekintve természetesen helyet kaptak - főleg az újság első felében - a korszakra jellemző politikai közlemények, felhívások és beszámolók is. Ezek közül kiemelkedtek a folyóirat sajátos rovatai (például Bankokos Manci, Fintor, Fullánk, Bankenciklopédia, Értelmező bankszótár stb.), humoros és verses írásai (például Tünődő Bankos Sebestyén). Ezeknek az egyszeri, vagy akár hosszú időn keresztül történő megjelenése karakteressé, egyedivé és nem utolsó sorban személyesebbé és közvetlenebbé tette az újságot az olvasók számára. A folyóiratban a bank hétköznapjait és ezzel kapcsolatos egyéb történéseit, valamint sport- és kulturális életét bemutató klasszikus írások, később fényképekkel színesített beszámolók és bemutatások mellett helyet kaptak a kritikusabb és csípősebb hangvételü cikkek is (például bürokrácia csökkentése, közérthető fogalmazás, egyhangú és drága ételek a büfében, a zsúfoltság, a munkaidő-pazarlás stb.).

A lap olvasottságát, illetve példányszámát erősen befolyásolta a Bank aktív dolgozói létszáma is, amely 1972-től lassú, majd 1986-tól egyre gyorsabb ütemben kezdett csökkenni. A folyóiratban végbemenő folyamatos megújulási kísérletek ellenére az újság nem volt képes megállítani a csökkenő tendenciákat, ami állandó és visszatérő problémaként merült fel a folyóirat életében egészen annak megszűnéséig.

\subsection{A Forint magazin titkos grafikusa}

Az illusztrációk és a rajzok döntő többségét 1945 és 1978 között Dr. Enyvvári Herbert készítette, aki a Magyar Nemzeti Bank jogásza volt, de életútja ennél sokkal többről árulkodik. 1916-ban született, és gyerekkorától kezdve a rajz volt a szenvedélye, illetve a képzőművészeti akadémia elvégzése. 1934-ben az érettségi után édesapjának a nyomására beiratkozik az akkori Pázmány Péter Tudományegyetem jogi és államtudományi karára. Az egyetemi évek alatt folyamatosan rajzol, több kiadótól (például Athenaeum, Dante, Cserépfalvi, Révai stb.) kap megbízást, és együtt dolgozik többek között Móricz Zsigmonddal, Karinthy Frigyessel, de Féja Gézával, 
Darvas Józseffel is társul a népi írók közül. Az általa illusztrált könyvek (például Bernáth Gusztáv mesekönyvei vagy Tamás István: Háry János legújabb kalandjai stb.) nem csak itthon, de nemzetközi szinten is sikeressé és népszerűvé tették. 1939-ben megszerzi a jogi doktori címet, majd egyszerre bevonul katonának. Csak 1943-ban tér haza egy fronton szerzett repesz okozta sebesülés miatt. Apja nyomására becsületes munka után néz, ekkor lép be a Magyar Nemzeti Bankba. Még ugyanebben az évben elkezd együtt dolgozni a Radnóti Miklós fordításában megjelenő Cervantes: Don Quijote illusztrációin. A költő és az illusztrátor között mély és őszinte barátság alakul ki. 1944 nyarán visszakéri magát a frontra, ahol ismét megsebesül, majd a szovjet előrenyomulás során fogságba esik. Csak 1945-ben kerül vissza ismét a Bankba munkaügyi jogászként, ahol később a belső szabályozások elkészítéséért is felel. Ekkor kezd el szenvedélyesen rajzolni a Forint folyóiratba is. Feleségével, Rákóczy Évával ${ }^{8}$, akit szintén itt, a bankban ismert meg, 1948-ban házasodtak össze. Enyvvári Herbert személyiségéről talán az alábbi visszaemlékezés az egyik legbeszédesebb: „életében mindig és minden eszközzel ellenállt az elnyomó hatalmak gépezetével szemben, még a háború utáni béke idején is. A kommunizmus alatt a bankban (!) két szatyor krumplival a kezében állta végig a kötelezö hivatalos ünnepi gyüléseket, hogy ne kelljen kényszerüen tapsolni" (Miklauzič, 2013b: 37). Enyvvári Herbert karikatúráit és illusztrációit a Forint hangulata egyik alappillérének tekinthetjük ${ }^{9}$. Hiába követték sokan mások ${ }^{10}$ ebben a pozícióban, rajzainak a kifinomultságát, a rá jellemző egyedi grafikai stílust, a belőlük fakadó humort és sajátos szemléletmódot lehetetlenség lett volna utánozni.

\section{Egyéb kiadványok}

Az 1965 és 1980 között megjelenő Referáló Lapok című sorozat (4. ábra) a szocialista országok általános közgazdasági és pénzügyi folyóirataiban megjelent cikkekből közölt ismertetéseket, számonként eltérő témák alapján. A sorozat arculatával teljesen megegyező az 1960-ban induló, de 1964 környékén arculati „frissítésen” áteső Tanulmányok címet viselő kiadványsorozat is (5. ábra).

\footnotetext{
${ }^{8}$ Rákóczy Éva, a nemesi Rákóczy-ág leszármazottja szintén 1945-ben került a Bankhoz. Először az Adóügyi Csoportnál, majd a Jogi Osztályon helyezték el. Egyik felmenője, Rákóczy János többek között „Kossuth titkára, legbensőbb bizalmasa, Damjanich János harcos barátja, Petőfi Sándor lelkes támogatója, Madách Imre és Jókai Mór kitartó barátja, a magyar hazafiak eszmetársa, az 1848/49-es szabadságharcot önálló lovasszázaddal is erősítő és a hadvezetés intézkedő, tekintélyt parancsoló alakja volt." (Miklauzič, 2013a: 5).

${ }^{9} \mathrm{Az}$ érdeklődő olvasók a Magyar Nemzeti Bank Könyvtárában megtekinthetik a digitalizált kiadványokat.

${ }^{10}$ Kezdetben Káspári András szintén jegybanki munkatárs vette át az illusztrációk készítését (1978-1979 között elvétve, majd döntően 1984-1990 között), illetve volt egy rövid közbenső időszak (1982-1983), amikor dr. Kesztyüs Ferenc munkái jelentek meg többségében a lapban. Az 1990-es évektől kezdve pedig már hivatásos karikaturisták, főleg Dluhopolszky László (DLUHO) és Dallos Jenő alkotásai (vagy azok újraközlései) jelentek meg a Forint magazin hasábjain.
} 


\section{4. ábra \\ A Referáló Lapok címú kiadványsorozat borítói 1977-ben}
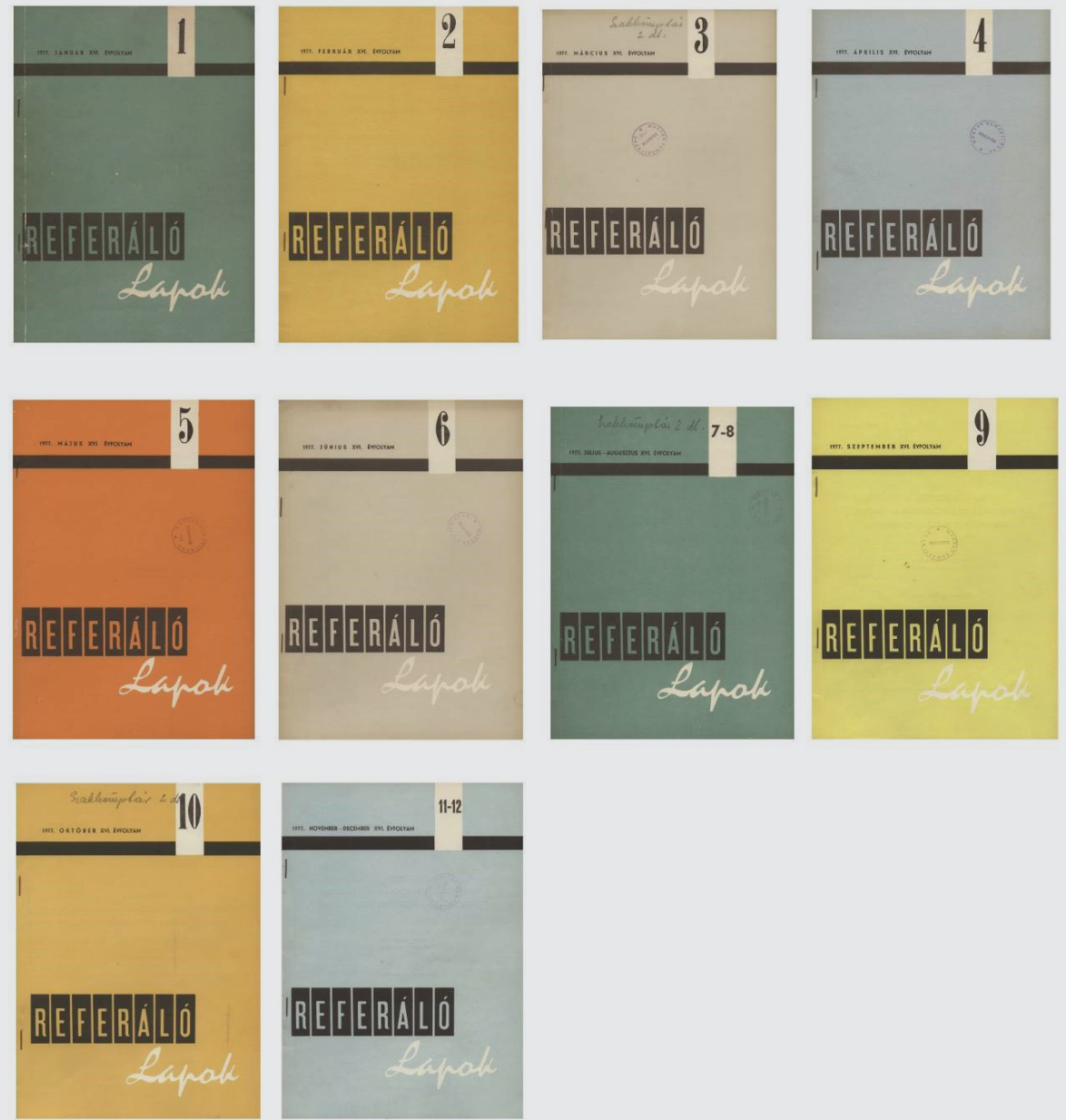


\section{5. ábra}

A Tanulmányok címú sorozat végleges borítói

(1963-1964 környékén)
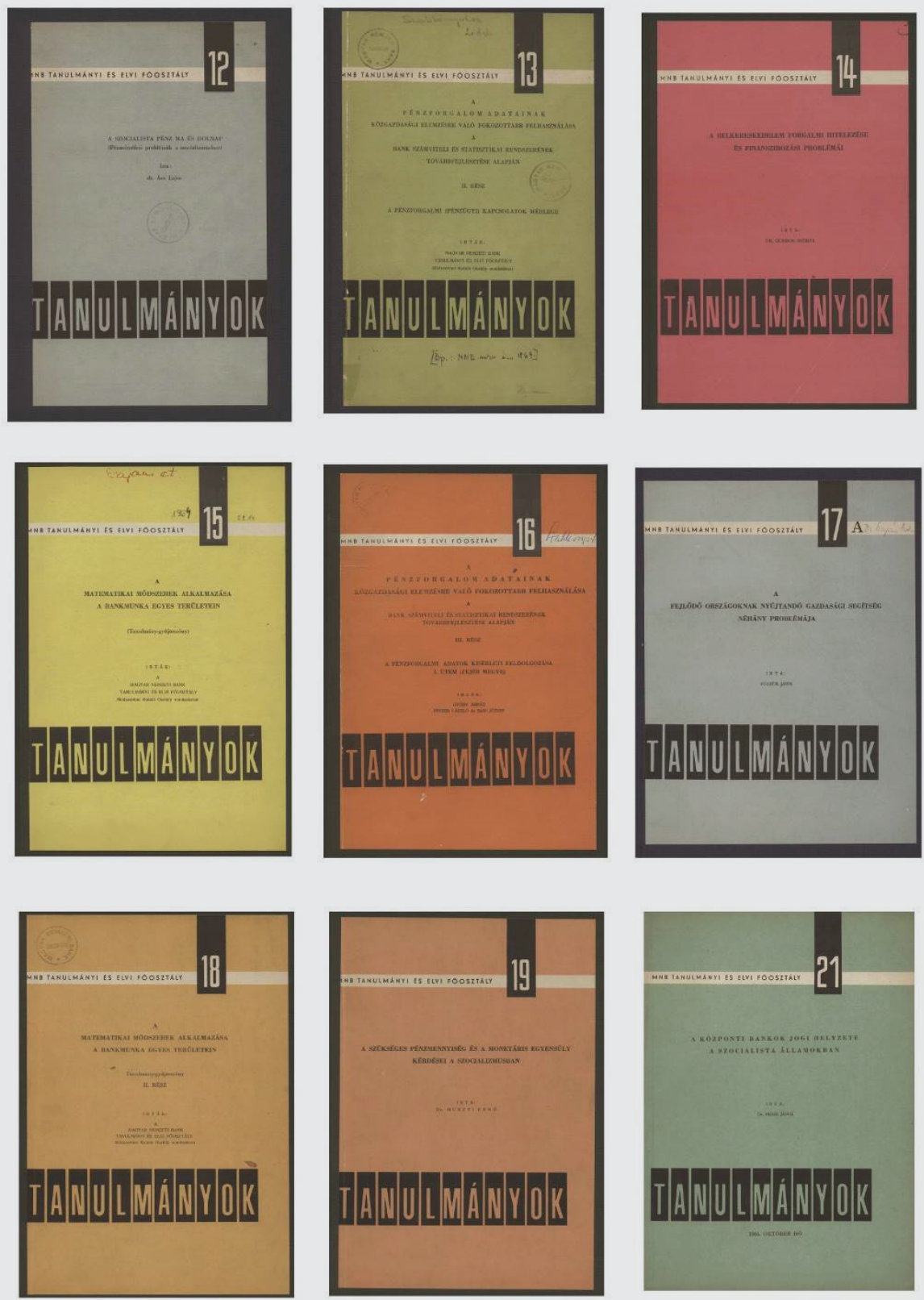
Mindkét sorozat kiadványainak a borítói különböző színekkel operálnak, de mégis bizonyos időközönként ismétlődő arculati világ jellemzi őket. A borítók változatossága, illetve az itt alkalmazott tipográfiai megoldások miatt is, talán - mai szemmel nézve - ez a két sorozat alkotta az egyik legizgalmasabb és legegységesebb vizuális képpel rendelkező sorozatát a Banknak ${ }^{11}$.

A Közgazdasági Irodalmi Szemle című kiadványt (6. ábra) a Közgazdasági Főosztály indította útjára. Az 1940 szeptemberétől 1944 júniusáig megjelenő kiadványsorozat (Botos 1999: 256-257) célja az volt, hogy támogassa és megkönnyítse a banki dolgozók szakmai tájékozódását a külföldi szakirodalmi recenziók közzétételével. A különböző hazai folyóiratokban ${ }^{12}$ megjelenő és kimondottan a banktevékenységre vonatkozó cikkek feldolgozása után a bemutatásokat hét témakörbe csoportosították ${ }^{13}$, majd így tették elérhetővé az olvasók számára. Ezzel szemben a Folyóiratszemle (6. ábra) az akkori szocialista országok pénz- és hitelgazdasági módszereiről, a szaklapokban megjelent elméleti cikkekről adott részletes tájékoztatást. A Könyvismertetések (6. ábra) pedig értelemszerűen egy-egy szakmai könyv bemutatását tǔzte ki céljául.

A Közgazdasági Föosztály Közleményei című szakmai kiadványsorozat (7. ábra) 1969 júliusa és 1989 augusztusa között jelent meg, ami a bank dolgozóinak különböző, hosszabb lélegzetvételű szakmai és tudományos tanulmányait, értekezéseit és öszszefoglalóit jelentette meg. Stílusában nagyon közel állt, mondhatni elődje volt az 1995 és 1996 fordulóján elindult MNB-Füzetekhez ${ }^{14}$, amelynek alapötlete Szapáry György ${ }^{15}$ nevéhez füződik, illetve a 2005 őszén elindult MNB Tanulmányokhoz ${ }^{16}$. A kiadványsorozat közel 30 éve alatt összesen 117 szám jelent meg, aminek érdekességét mégsem a borító szokatlanul egyedi és a bank világába egyáltalán nem illő elrendezése és tipográfiai megoldásai adják, hanem az, hogy megjelenésétől kezdve - egészen a megszúnéséig - képes volt változatlan külső arculattal és struktúra mentén megjelenni.

${ }^{11}$ Komoly hasonlóság mutatkozik az akkori borítók stílusjegyei, illetve a jelenleg nagy népszerűségnek örvendő Harvard Business Review (HBR) Press különböző zsebkönyvsorozatainak a hangulatvilága között. Mindkettő letisztult, egyszerű színeket és tipográfiát használt fel kiadványborítóinak elkészítéséhez. A különbség „csak” annyi, hogy a HBR sorozatain szemléltető jellegű illusztrációk is találhatók.

${ }^{12}$ A Bankszemle, a Gazdaság, a Közgazdasági Szemle, a Külkereskedelem, a Pénzügyi Szemle és a Társadalmi Szemle.

${ }^{13}$ Általános pénzügyi kérdések, jövedelemszabályozás, költségvetés, hitelezés, pénzforgalom, devizagazdálkodás és külkereskedelem, beruházások pénzügyi kérdései.

${ }^{14}$ Az MNB Füzetek kezdetben magyar nyelven, majd igazodva a hasonló jellegú nemzetközi kiadványokhoz, később már csak angol nyelven jelent meg, illetve ennek megfelelően a sorozat is átnevezésre került $M N B$ Working Papers névre, amely a mai napig megjelenik.

151993 és 1999, illetve 2001 és 2007 között a Magyar Nemzeti Bank alelnöke, jelenleg a Magyar Nemzeti Bank elnöki főtanácsadója.

${ }^{16}$ Az MNB-Tanulmányok a 2005 ősz előtt megjelenő MNB Háttértanulmányok és az MNB Mühelytanulmányok sorozatot vonta össze és a mai napig megjelenik a Magyar Nemzeti Bank gondozásában. 


\section{6. ábra}

A Könyvismertetések, a Folyóiratszemle és a Közgazdasági Irodalmi Szemle borítóinak stílusváltása
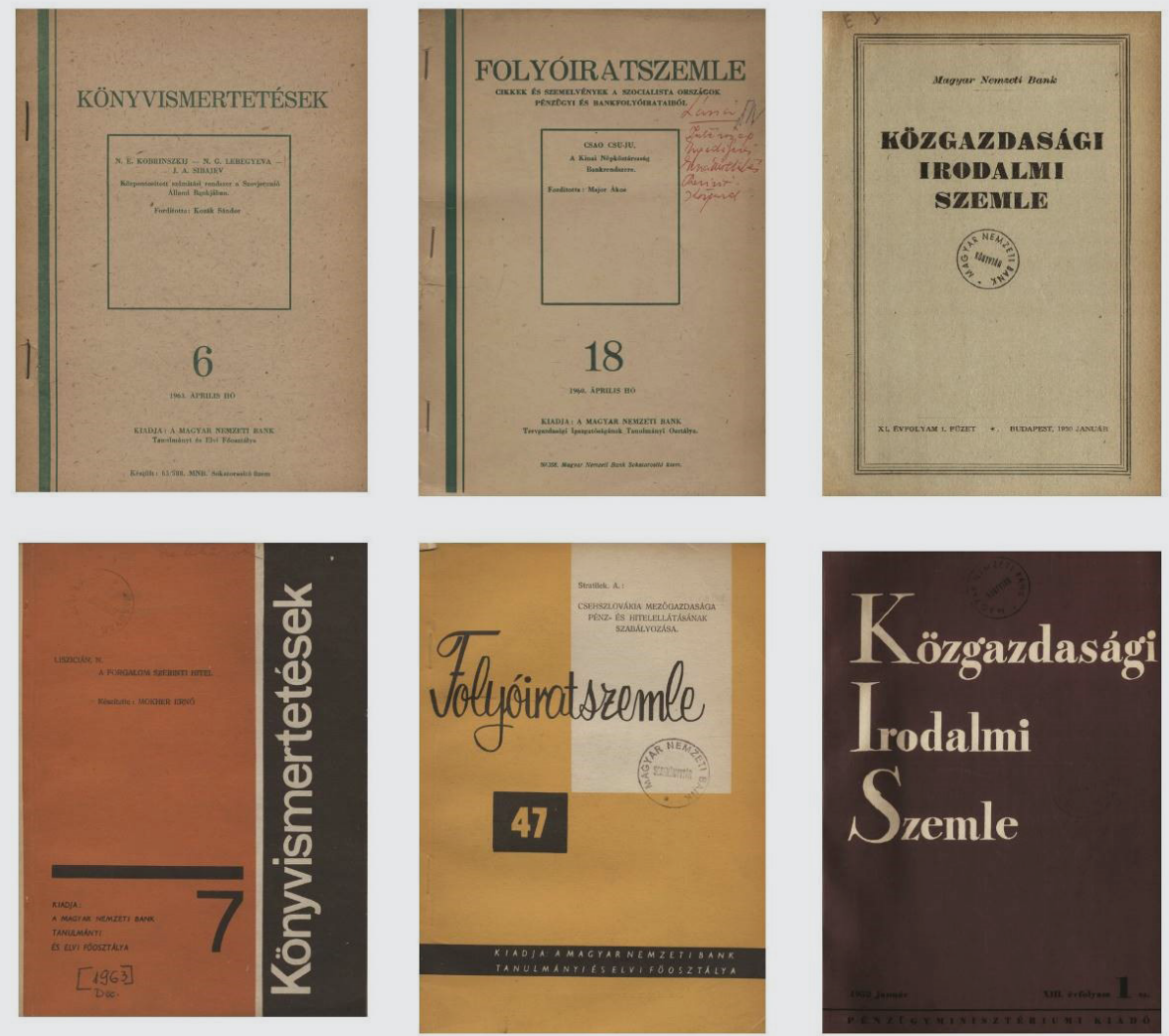


\section{7. ábra}

A Közgazdasági Főosztály Közleményei címú kiadvány borítója 1969-ben (1. szám) és 1983-ban (107. szám)
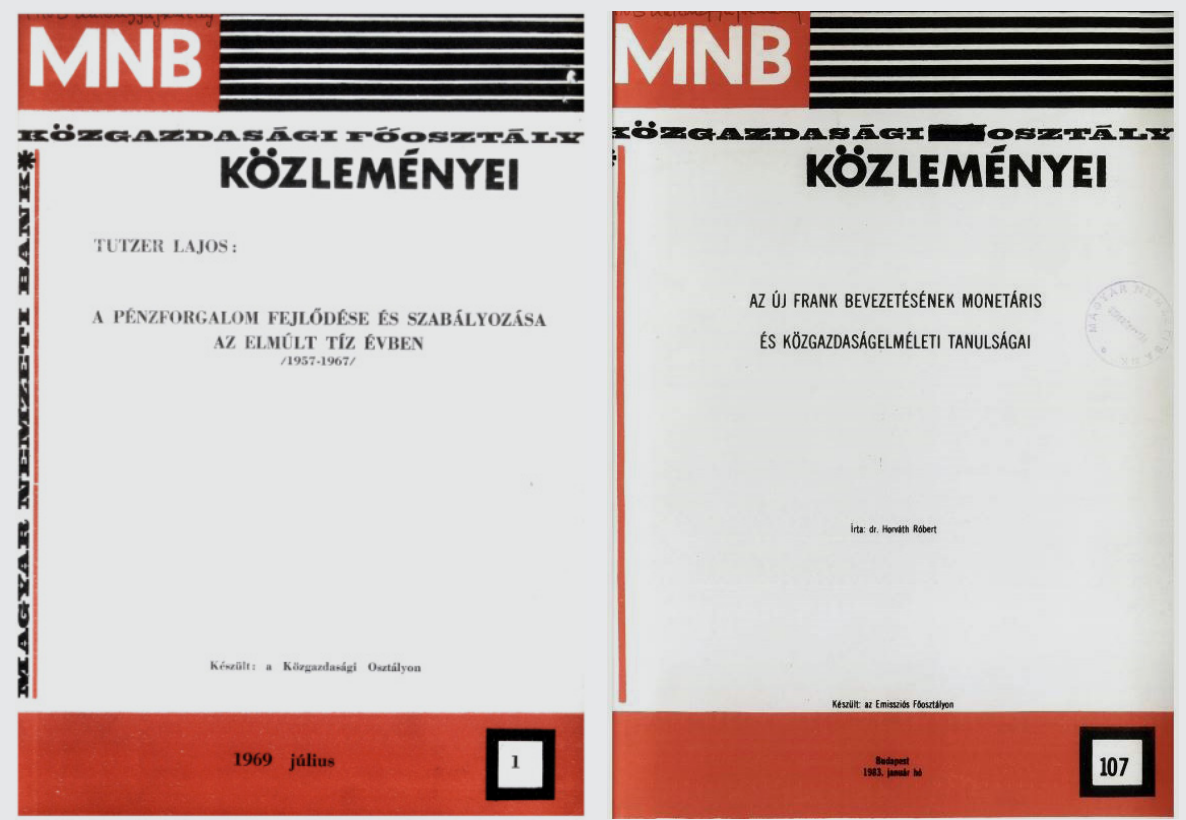

Megjegyzés: A képen azért az 1983-ban kiadott 107. szám került feltüntetésre, mert innentöl kezdve a későbbi számok fekete-fehér színben voltak csak elérhetöek a Magyar Nemzeti Bank digitális archivumában (Nainuwa). A színeket leszámítva azonban a borítón minden ugyanúgy nézett ki, mint az azt megelőző számok esetében. A vizuális folytonosság szemléltetése érdekében azonban mégis az archivumban elérhetö legutolsó színes borítós szám került feltüntetésre.

A kiadványok közül megemlítendő még az 1952-ben létrejövő Oktatási osztály ${ }^{17}$ által kiadott sorozat (8. ábra) is. A szervezet feladata a Bank akkori belső és részben külső szakmai képzéseinek egységes felügyelete (Botos - Botos 2004: 138). Feltételezhetően ennek érdekében kerültek kiadásra 1953-tól azok a döntően belső használatú, különböző példányszámban készülő kiadványok, amelyek átfogó és tömör szakmai útmutatást, feladatleírást adtak egy-egy témakör, feladatkör kapcsán a kollégák számára. A kiadványokat a Pénzügyi Kiadó adta ki, és a borítók arculatát tekintve egy visszafogott színeket alkalmazó (szürke, fehér, sötétbarna) borító került kialakításra.

\footnotetext{
${ }^{17}$ A kiadványok kiadását végző Oktatási Osztályt 1952 novemberében hozták létre. Az osztály felállításának célja az volt, hogy 1950-1956 között létrejövő területi irodákból, megyei fiókokból és fiókirodákból álló országos hálózatban dolgozók szakmai képzéséhez nyújtson támogatást. Az osztályt 1955-ben - három év fennállás után - megszúntették, azaz beolvasztották az akkori Személyügy alá.
} 
A Magyar Nemzeti Bank 1950 és 1990 között megjelenő, magyar nyelvü...

\section{8. ábra}

A Magyar Nemzeti Bank Oktatási Osztálya által kiadott kiadványok borítói 1953-ban
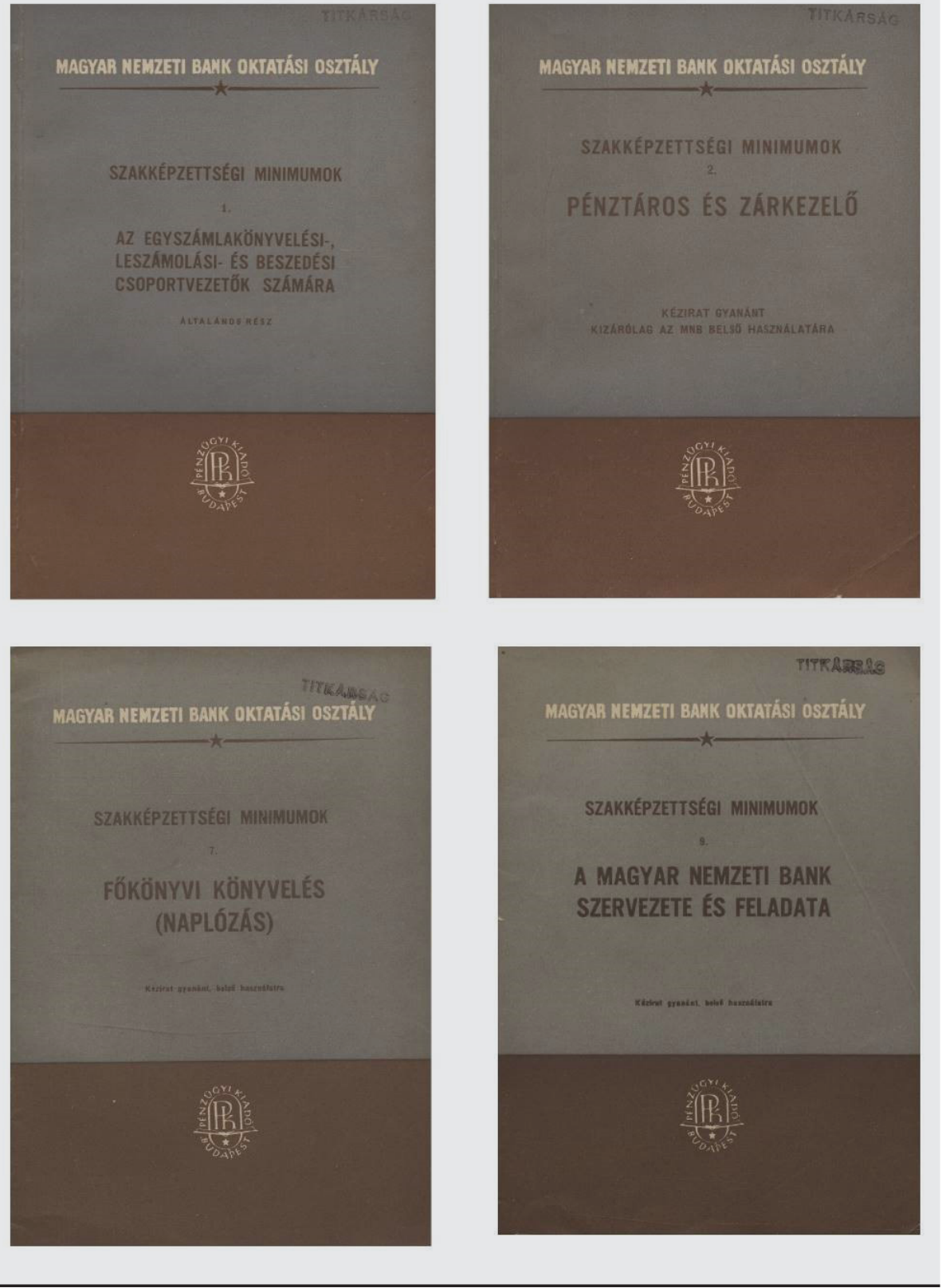


\section{5. Összefoglalás}

Napjainkban a vizualitás, azon belül is a vizuális kommunikáció fontossága megkérdőjelezhetetlen. A kommunikáció módja, csatornája, felépítése és a „külső csomagolása" is - bármennyire is mellőzhető és elhagyható folyamatnak tűnik - kritikus fontosságú, és megkerülhetetlen részét kell képeznie a szakmai- és tudományos közéletnek is. A vizualitás és a vizuális kommunikáció ugyanis jellegénél fogva figyelemfelhívó és irányító jelleggel bír, ami elősegítheti a szakmai tartalmak feldolgozásának a folyamatát. Egy olyan világban, ahol az elérhető információk mennyisége napról-napra megsokszorozódik, nem lehetetlen, de jóval nehezebb kitűnni a szakmai kommunikáció „zajából”. Egy jól felépített, régóta egységes vizuális arculattal rendelkező szervezet, folyóirat vagy kiadványsorozat képes folytonosságot, stabilitást és megbízhatóságot kommunikálni a külső világ felé. Egy szervezet birtokában lévő szakmai anyagok vizuális arculatának a megismerése, strukturálása és rendszerezése lehetőséget teremt arra, hogy hosszabb távon - saját vizuális gyökereire támaszkodva - felépítsen egy olyan bázist, amellyel platformot teremthet, hogy szakmai tartalmai még látványosabban kiemelkedjenek a többi közül, ezáltal felhívva magára a figyelmet. Véleményem szerint a jelenlegi feldolgozás nemcsak különlegessége miatt válhat érdekessé, hanem azáltal is, hogy a jövő számára olyan szempontokra hívhatja fel a figyelmet, amivel hozzájárulhat a Banknak és kiadványainak további belső és külső vizuális kommunikációs fejlődéséhez.

\section{Felhasznált irodalom}

Botos János (1999): A Magyar Nemzeti Bank története II. kötet - Az önálló jegybank 19241948. PressCon Kiadó Kft, 399 p.

Botos János - Botos Katalin (2004): A Magyar Nemzeti Bank története III. kötet - A jegybank útja rendszerváltozástól rendszerváltozásig 1948-1989. Tarsoly Kiadó, Budapest, 753 p.

Miklauzič István (2013a): A nemesi Rákóczy-család. Történelmi életutak. Mécses Sorozat, Székely Ház Közhasznú Alapítvány, 137 p.

Miklauzič István (2013b): A Mikó - Nyiredy - Arlow család. Prémszövők, méneskariak és a rendithetetlenek kopjafája. Mécses Sorozat, Székely Ház Közhasznú Alapítvány, 196 p. 